\title{
PROSES NEGOSIASI KONFLIK PAPUA: DIALOG JAKARTA-PAPUA
}

\author{
Delvia Ananda Kaisupy ${ }^{1 *}$, Skolastika Genapang Maing ${ }^{1}$ \\ ${ }^{1}$ Universitas Muhammadiyah Yogyakarta, Indonesia \\ *e-mail: kaisupydelvi@gmail.com
}

\begin{abstract}
Abstrak
Konflik Papua merupakan konflik vertikal dan berlangsung lebih dari 50 tahun. Penyebab utama konflik ini adalah keinginan untuk "Papua Merdeka" yang diperjuangkan oleh Organisasi Papua Merdeka (OPM). Konflik ini juga semakin memanas dengan keberadaan Freeport serta isu rasial dan diskriminasi terhadap mahasiswa Papua di Surabaya dan Malang pada bulan agustus 2019. Negosiasi menjadi pilihan terbaik Pemerintah Indonesia untuk resolusi konflik di Papua. Tujuan utama artikel ini adalah untuk memahami proses negosiasi konflik Papua terkait aktor, tuntutan dan proses negosiasi dengan menggunakan teori negosiasi. Penelitian menggunakan metode kualitatif, dimana penelitian dilakukan terhadap fenomena sosial masyarakat yang secara wajar dan alamiah terjadi tanpa adanya rekayasa atau laboratoris. Pendekatan ini memberikan data-data yang sifatnya deskriptif berupa perkataan tertulis atau lisan yang menggambarkan berbagai kondisi dan situasi atau variabel tertentu. Teknik pengumpulan data adalah dengan menggunakan studi literatur untuk memperoleh data yang dibutuhkan. Hasil penelitian menunjukkan bahwa proses negosiasi konflik Papua melibatkan aktor internal (pemerintah pusat/daerah, KKB/OPM, kepala suku/tokoh agama dan masyarakat sipil) dan aktor eksternal (Freeport) dengan tuntutan utama adalah Papua merdeka. Proses negosiasi berlangsung lama dan menghadapi banyak kendala, namun hal ini akan terus diusahakan untuk mendapatkan keputusan yang bersifat win-win solution. Dialog antara Jakarta-Papua harus lebih mencerminkan nilai-nilai budaya orang Papua.
\end{abstract}

Kata kunci: Freeport; Konflik; Negosiasi; OPM; Papua

\begin{abstract}
Papua conflict was a conflict of the vertical and lasted more than 50 years. This conflict's leading cause was the desire to "free Papua movement" championed by the Organization of Papua Merdeka (OPM). This conflict was also increasingly heating up with Freeport's presence and the issue of racial profiling and discrimination against Papua students in Surabaya and Malang in August 2019. Negotiations are the best option for the Indonesian Government to conflict resolution in Papua. The primary purpose was to understand the negotiation conflict process in Papua related to the actor, the demands, and the negotiation process by using the theory of negotiations. The author used qualitative research methods, where research was carried out on social phenomena that naturally and naturally occur without any engineering or laboratory. The results showed that the Papua conflict negotiation process involved internal actors (central/regional government, KKB/OPM, tribal/religious leaders, and civil society) and external actors (Freeport), with the main demand being an independent Papua. The negotiation process took a long time and faced many obstacles. However, efforts would continue to be made to obtain a win-win solution. The dialogue between Jakarta and Papua must better reflect the cultural values of the Papuan people.
\end{abstract}

Keywords: Freeport; Conflict; Negotiation; OPM; Papua

This is an open access article under the CC BY-SA license.

Copyright @ 2021 by Author. Published by Universitas Pendidikan Ganesha.

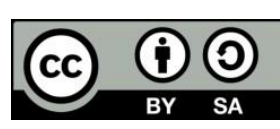




\section{PENDAHULUAN}

Negara

memproklamasikan kemerdekaannya pada 17 Agustus 1945. Proklamasi kemerdekaan tersebut menandai dimulainya perlawanan diplomatik dan bersenjata dari Revolusi Nasional Indonesia terhadap pasukan Belanda dan warga sipil pro-Belanda. Indonesia juga mengklaim kepemilikan seluruh wilayah Hindia Belanda di Indonesia, termasuk wilayah Indonesia bagian barat yaitu Pulau Papua. Namun klaim ini dibantah oleh Belanda karena pihak Belanda menganggap wilayah tersebut masih menjadi salah satu provinsi dari Kerajaan Belanda. Dalam Konferensi Meja Bundar tahun 1949, status Papua Barat kemudian dibahas oleh Belanda dan Indonesia dan tidak berhasil mencapai kesepakatan akhir. Namun kedua pihak setuju untuk kembali membicarakan masalah ini dalam jangka waktu satu tahun kemudian. Melalui Forum Perserikatan BangsaBangsa (PBB) yang diadakan bulan Desember 1950, status Papua Barat kembali dibicarakan. PBB memutuskan bahwa Papua Barat mempunyai hak untuk merdeka berdasarkan peraturan yang tertuang dalam Piagam PBB pasal 73 (e) (United Nations, 1945). Namun keputusan ini tidak langsung diterima oleh Belanda dan Indonesia. Klaim kepemilikan Papua Barat terus dilakukan oleh Indonesia sehingga Belanda kembali mengundang Indonesia ke Makamah Internasional untuk menyelesaiakan masalah ini. Namun undangan pihak Belanda tersebut kembali di tolak Indonesia. Indonesia terus melakukan penyerangan untuk merebut Papua dari tangan Belanda. Untuk mengatasi perlawanan dari Indonesia, Belanda memutuskan untuk mempercepat persiapan kemerdekaan Papua Barat (Firdausi, 2019).

Pada tahun 1961, Pemerintah Belanda memulai persiapan untuk membentuk Papua Barat sebagai negara merdeka yang terlepas dari negara Indonesia. Belanda mempercepat program pendidikan di Papua Barat untuk persiapan kemerdekaan. Salah satu hasilnya adalah dengan membentuk akademi angkatan laut dan tentara Papua.Belanda kemudian mendeklarasikan kemerdekaan Negara Papua pada tanggal 1 Desember 1961 di Hollandia (sekarang menjadi kota Jayapura) melalui Komite Nasional Papua (KNP) yang dibentuk Belanda. Negara Papua diberi nama "West Papua" dengan lambang negara "Burung Mambruk", bendera "Bintang Kejora", lagu Kebangsaan "Hai Tanahku Papua" dan semboyan negaranya "One People One Soul".

Menghadapi politik dekoloniasasi ataupun langkah yang diambil oleh Belanda untuk pembentukan Negara Papua Barat, maka Presiden Soekarno mencetuskan Tri Komando Rakyat (Trikora) pada tanggal 19 Desember 1961 di Yogyakarta. Trikora sebagai bentuk perjuangan Indonesia merebut Papua dengan melakukan seranganserangan militer terbatas terhadap Belanda di Papua Barat. Di sisi lain, untuk modernisasi perlengkapan militer Presiden Soekarno mulai mendekatkan diri pada negara komunis terutama Uni Soviet. Sikap Soekarno tersebut membuat takut Belanda dan Presiden Amerika Serikat John F Kennedy. Hal ini disebabkan adanya pemikiran bahwa jika kedekatan Indonesia dan Uni Soviet dibiarkan, maka Indonesia sangat mungkin menjadi negara komunis terbesar di Asia Tenggara. Ketakutan itu lalu membuat Belanda mengambil sikap untuk menyerahkan masalah Papua ke PBB. Dengan diserahkannya masalah Papua ke PBB, Belanda memutuskan untuk keluar dari Papua dan berhenti merebut atau menjajah Papua. Papua kemudian diserahkan kembali ke Indonesia dengan syarat memberi kesempatan pada rakyat Papua untuk menentukan sikap sendiri atau referendum Penentuan Pendapat Rakyat (PERPERA). Lewat PERPERA tahun 1969, rakyat Papua memilih "tetap" dalam lingkungan negara Republik Indonesia.

Namun pelaksanaan referendum ini ternyata banyak menuai protes. 
Pemungutan suara "pilihan bebas" (free choice) yang diterapkan oleh PBB melibatkan lebih dari 1000 kepala suku yang dipilih sebagai perwujudan dari "konsultasi" lokal (dari perkiraan jumlah penduduk waktu itu 800.000 orang) dan bukannya dengan mengadakan pemungutan suara dengan cara satu orang satu suara. Masalah keterwakilan politik di atas terkait dengan pendekatan tanpa melibatkan penduduk Papua dalam proses pembuatan keputusan dalam keberadaan hidup mereka. Hal tersebut berakibat pada keluhan-keluhan sejarah yang berakar dari perbedaan persepsi mengenai integrasi Papua ke dalam Negara Indonesia. Selama sejarah integrasi Papua tidak dianalisis secara kritis dan terbuka guna menemukan sejarah bersama, maka keluhan historis akan tetap ada (Centre for Humanitarian Dialogue, 2011).

Organisasi Papua Merdeka (OPM) adalah istilah umum bagi gerakan pro kemerdekaan Papua yang tidak puas dengan kebijakan pemerintah Indonesia selama Papua terintegrasi dengan Indonesia. OPM adalah kelompok bersenjata yang sering menyebabkan konflik di Papua. Pergerakan dan perjuangan OPM terjadi di berbagai tempat di Papua berlangsung sejak 1967 hingga 2001. $R$ $Z$. Leirissa dalam bukunya yang berjudul "Sejarah Proses Integrasi Irian Jaya" tahun 1992 menilai gerakan separatis yang dilakukan OPM dan serangkaian peristiwa terkait yang terjadi di Papua adalah hasil dari didikan Belanda yang sewaktu-waktu akan meledak. Dengan cara pandang seperti ini Leirissa terkesan menyalahkan pihak asing atas kegagalan pemerintah Indonesia mengelola konflik Papua selama Papua terintegrasi dengan Indonesia (Rycho Korwa, 2013).

Gerakan OPM tidak semata-mata sebagai suatu gerakan politik atau gerakan perlawanan gerilya. OPM lahir setelah serangkaian pertarungan kekuasaan yang melibatkan Pemerintah RI, Amerika Serikat, United Nations Temporary Executive Authority
(UNTEA), Pemerintah Belanda, dan sejumlah elite terdidik Papua yang berlangsung sejak 1962-1969. Sejak itu sebagian elite Papua pimpinan OPM membangun perlawanan dan mencoba melibatkan rakyat dalam usahanya "merebut kembali" kemerdekaan Papua Barat yang sempat mereka proklamasikan pada 1 Desember 1961. Pemberontakan OPM disebabkan ketidakpuasan dan kekecewaan orang Papua karena mulai awal integrasi rakyat Papua ditekan dan diintimidasi oleh pemerintah Indonesia. Sedangkan menurut antropolog George Junus Aditjondro, gerakan separatisme dan gelombang perlawanan baik bersenjata maupun non-bersenjata di Papua berkembang seiring intensitas kekerasan yang dilancarkan aparat keamanan Indonesia di Papua (Syamsul Hadi and Andi Widjajanto, 2007).

Keberadaan OPM di Papua terus menyulut konflik yang berkepanjangan. Untuk menjaga kedaulatan NKRI, maka usaha yang cukup serius dilakukan oleh Pemerintah Indonesia untuk menangani konflik di Papua. Usaha Pemerintah Indonesia ini dimulai sejak tahun 1999 dengan penetapan provinsi tersebut sebagai Daerah Otonomi Khusus (Otsus). Hal ini diharapkan akan mengurangi jurang antara Papua dan Provinsi lainnya. Kenyataannya, walaupun Undang-undang Otonomi Khusus mengakomodasi beberapa aspirasi dari banyak rakyat Papua dan menawarkan kemungkinan kerangka untuk kestabilan, dalam waktu hampir 10 tahun sejak penetapannya, tidak terjadi perbaikan pemerintahan dan pembangunan yang signifikan, sehingga rakyat Papua menjadi kecewa karenanya. Dengan demikian, Pemerintah Indonesia melakukan pendekatan alternatif melalui dialog untuk menyelesaikan konflik Papua. Dialog sebagai salah satu upaya negosiasi Pemerintah Indonesia bersama masyarakat Papua. Proses negosiasi konflik Papua dilakukan secara internal antara Pemerintah dan masyarakat Papua, serta secara 
eksternal melalui organisasi internasional seperti PBB.

Penelitian terkait konflik Papua telah banyak dilakukan oleh peneliti sebelumnya. Penelitian tersebut banyak terdapat dalam buku, artikel ataupun jurnal yang membahas kajiankajian permasalahan konflik Papua. Penelitian Azmi Muttaqin (2014) yang berjudul Otonomi Khusus Papua sebuah Upaya Merespon Konflik dan Aspirasi Kemerdekaan Papua mengemukakan bahwa Otonomi khusus dirasa dapat menjadi suatu penyelesaian dan kebijakan alternatif terbaik dalam mewujudkan seluruh keinginan masyarakat Papua dalam bingkai NKRI. Di satu sisi mereka menuntut kemerdekaan, tetapi di sisi lain dapat menjadi semacam pelembagaan penguatan nasionalisme Papua. Hal ini akan terus memperkuat semangat nasionalisme dan identitas etnis Papua yang mungkin kontraproduktif dengan tujuan memperkuat sentimen nasionalisme dan identitas bangsa Indonesia (Muttaqin, 2014). Sejalan dengan penelitian Muttaqin, hasil penelitian Nur Rohim (2014) dalam tulisannya yang berjudul Optimalisasi Otonomi Khusus Papua dalam Peningkatan Kesadaran Hukum Masyarakat guna Meredam Konflik dan Kekerasan menunjukkan bahwa otonomi khusus yang diberikan kepada Papua harus dioptimalkan guna meredam konflik dan kekerasan yang terjadi di Papua. Dengan demikian tujuan untuk memakmurkan dan mensejahterahkan masyarakat Papua di tanah leluhur dapat terwujud (Rohim, 2014).

Disisi lain penelitian terkait dengan resolusi konflik Papua ditulis oleh Yoseph Yapi Taum (2015) dalam tulisannya yang berjudul Kekerasan dan Konflik di Papua: Akar Masalah dan Strategi Mengatasinya. Yoseph menjelaskan terkait dengan akar masalah yang terjadi di Papua dan bagaimana strategi untuk menyelesaikannya, dimana dibutuhkan solusi yang komprehensif terkait ekonomi, politik yang dibarengi dengan pendekatan kultural (Taum, 2015).
Selain itu, analisis terkait resolusi konflik Papua juga dikemukakan oleh Siti Humairoh (2018) dalam tulisannya yang berjudul Analisis Penggunaan Diplomasi Multi Jalur untuk Mendukung Penyelesaian Konflik Papua Barat Tahun 2009-2018. Siti menggunakan konsep Track Diplomacy yang dikemukakan oleh Diamond dan McDonald untuk menjelaskan penggunaan diplomasi oleh aktor negara dan non negara dalam proses mencapai resolusi konflik di tanah Papua (Humairoh, 2018). Dan penelitian terbaru adalah yang ditulis oleh Aldiano Hadi Nugroho (2019) yang berjudul Kebijakan Pemerintah Joko Widodo dan Jusuf Kalla dalam Upaya Membangun Dialog untuk Penyelesaian Konflik Vertikal Papua Tahun 20142019. Aldiano menjelaskan upaya yang dilakukan Pemerintah Jokowi dan Jusuf Kalla dalam membangun dialog untuk menyelesaikan konflik di tanah Papua sebagai paradigma pemerintah yang baru. Hasil penelitian menunjukkan bahwa pemerintahan Jokowi dan Jusuf Kalla mengalami tantangan karena paradigma dialog mengalami miskonsepsi, dimana pendekatan dan konsep belum tepat serta adanya berbagai faktor yang menjadi akar dari masalah yang terjadi. Faktor yang dimaksud adalah sejarah integrasi dan identitas, kekerasan politik, kegagalan pembangunan, dan marjinalisasi orang Papua (Nugroho, 2019).

Berdasarkan beberapa tinjauan pustaka tersebut, diketahui bahwa penulis terdahulu telah melakukan penelitian yang beragam mengenai konflik yang terjadi di Papua. Namun penelitian-penelitian tersebut belum memberikan penjelasan yang menyeluruh terkait dengan proses negosiasi konflik serta dialog seperti apa yang harus dilakukan oleh pemerintah dalam upaya resolusi konflik di Papua.

\section{METODE}

Metode yang digunakan pada penelitian ini adalah menggunakan metode penelitian kualitatif. Dimana menurut Bodgan dan Taylor, 
metodologi kualitatif adalah prosedur penelitian yang menghasilkan data deskriptif berupa kata-kata tertulis atau lisan dari orang-orang dan perilaku dapat diamati. Pendekatan ini diarahkan pada latar dan individu tersebut secara utuh (Moleong, 2002). Sedangkan menurut Nawawi pendekatan kualitatif dapat diartikan sebagai rangkaian atau proses menjaring informasi, dari kondisi sewajarnya dalam kehidupan suatu obyek, dihubungkan dengan pemecahan suatu masalah, baik dari sudut pandang teoritis maupun praktis. Penelitian kualitatif dimulai dengan mengumpulkan informasi-informasi dalam situasi sewajarnya, untuk dirumuskan menjadi suatu generalisasi yang dapat diterima oleh akal sehat manusia (Hadari, 1992). Oleh karena itu, pendekatan kualitatif ini dipilih oleh penulis beradasarkan tujuan penelitian untuk mengungkapkan aktor-aktor, tuntutan dan proses negosiasi terkait konflik Papua sebagai upaya resolusi konflik di tanah Papua.

Dilihat dari jenis penelitian, maka penelitian ini adalah deskriptif. Pada jenis penelitian deskriptif, data yang dikumpulkan berupa kata-kata, gambar dan bahkan angka-angka. Dengan demikian, laporan penelitian akan diberi kutipan-kutipan data untuk memberikan gambaran penyajian laporan tersebut (Bunga, 2003). Tulisan ini difokuskan pada kajian kepustakaan, dimana penulis membaca karya-karya yang terkait dengan tema yang diangkat. Sumber data yang digunakan oleh penulis adalah buku, jurnal/artikel, laporan terkait konflik di Papua dan sumber daring serta media massa yang digunakan untuk mendukung argumentasi penulis. Teknis analisis dilakukan dengan membaca hasil penelitian, mencermati, dan mencatat hal-hal penting yang membuktikan argumentasi penelitian.

\section{HASIL DAN PEMBAHASAN}

Konflik berkaitan erat dengan kehidupan manusia. Demikian pula dalam hubungan internasional. Konflik dapat menjadi salah satu pembentuk pola interaksi antar aktor dalam suatu sistem internasional. Herz (Hertz, 1950) dan Waltz (Waltz, 1959) mengemukakan bahwa negara-negara di dunia terjebak dalam sistem internasional yang konfliktual. Hal ini disebabkan kebiasaan suatu negara untuk bertahan hidup dalam sistem adalah dengan cenderung meningkatkan kemampuan diri sebagai bentuk kesiapan dan pencegahan dari adanya serangan. Berbagai macam konflik yang terjadi di dunia baik konflik antar negara maupun konflik internal/domestik telah menemukan titik terang dan digantikan dengan perdamaian antara pihak-pihak yang berselisih berkat adanya resolusi konflik yang diusahakan oleh pihak-pihak tersebut. Akan tetapi tidak sedikit juga konflik yang saat ini sedang/masih berlangsung hingga bertahun-tahun lamanya. Salah satunya adalah konflik yang terjadi di tanah Papua.

Pada kodratnya konflik Papua memiliki sejarah dan proses yang panjang. Konflik ini sudah berlangsung lebih dari 50 tahun dan memakan banyak korban baik dari pihak OPM, TNI/Polri dan warga sipil. Konflik Papua juga mengalami transformasi dalam bentuk perjuangannya, dimana pada awalnya OPM memperjuangkan kemerdekaan menggunakan cara kekerasan berubah menjadi nonkekerasan dengan memanfaatkan dialog internasional dan media informasi. Namun, hal ini tidak menutup kemungkinan jika penggunaan senjata masih menjadi pilihan untuk alasan perlindungan diri. OPM mulai melibatkan diri dalam sidang maupun konfrensi internasional lewat para pemimpinnya untuk menarik perhatian internasional (Hadi, 2016). Transformasi konflik tidak terjadi sebatas bentuk dari perjuangan OPM, transformasi juga terjadi terkait penyebab konflik di Papua. Dewasa ini, isu rasial dan diskriminasi menjadi faktor penyebab konflik internal di Papua. Masalah ini kemudian digunakan oleh kelompok separatis untuk kembali menyulut dan memanaskan konflik di Papua. Hal ini 
menyebabkan terjadinya tindak kekerasan dengan membakar dan merusak fasilitas umum di Papua. Oleh karena itu, penanganan konflik ini sangat penting agar tidak memakan lebih banyak korban.

Menurut Wallensteen (2002) menjelaskan tiga komponen yang mendukung terjadinya konflik yaitu tindakan, inkompatibilitas, dan aktor. Tindakan merupakan hal yang menandakan adanya konflik, walaupun tidak semua ketiadaaan tindakan berarti berakhirnya konflik. Contohnya gencatan senjata, meskipun menghentikan tindakan yang mendukung konflik tetapi sifatnya hanya sementara karena konflik masih mungkin terjadi yang memicu tindakan selanjutnya. Oleh karena itu, definisi konflik dijelaskan lebih rinci dengan komponen inkompatibilitas. Adanya ketidakcocokan antara kedua belah pihak atau lebih yang berusaha memperoleh sumber daya yang memicu terjadinya tindakan yang mengarah ke konflik. Ketika para pihak ini menyesuaikan tuntutannya dan kelangkaan dari sumber daya yang diperebutkan tidak terjadi lagi maka konflik akan selesai. Selain dua komponen tersebut, ada komponen aktor yang merupakan dasar terjadinya konflik. Pemahaman para aktor tentang peran dan sumber daya mereka merupakan hal yang penting dalam menganalisis suatu konflik. Pemahaman mereka akan pentingnya kebutuhan untuk bertahan hidup mengakibatkan munculnya konflik dalam sistem (RA, Dermawan, \& Akim, 2019).

Salah satu cara dalam penyelesaian konflik adalah melalui negosiasi di antara pihak-pihak yang berselisih. Lopez-Fresno, dkk (2018) mengutip definisi negosiasi oleh Llamazares (2011) sebagai proses yang dilakukan oleh dua pihak atau lebih sebagai bentuk komunikasi untuk mencapai kepentingan bersama dengan cara mengedepankan kepentingan dan mengurangi perbedaan (Fresno, Savolainen, \& Miranda, 2018). Ada dua macam pendekatan yang dapat dilakukan dalam negosiasi, yaitu pendekatan distributif dan pendekatan integratif. Negosiasi distributif menggunakan zero-sum game, dimana ada salah satu pihak yang harus merelakan kepentingannya sehingga menciptakan adanya iklim konfrontasi. Sebaliknya, negosiasi integratif mementingkan terselesainya solusi dengan memerhatikan kepentingan semua pihak yang terlibat. Masing-masing pihak selain vokal dalam memperjuangkan kepentingannya, juga mempertimbangkan kepentingan pihak yang lain. Dalam mencapai solusi, para pihak harus memahami situasi dan mengidentifikasi kepentingan masingmasing. Untuk itu, dalam negosiasi integratif diperlukan adanya kepercayaan, kerjasama, dan arus informasi yang lancar di antara para pihak (Hames, 2012). Negosiasi integratif menekankan pada adanya pemahaman masing-masing pihak yang merasa menjadi kontributor dalam negosiasi, bukan sebagai pesaing dari pihak lainnya (Llamazares \& Nieto, 2011). Non-zero-sum game yang dipraktikkan dalam negosiasi integratif dapat tercapai dengan adanya normanorma yang mengikat para pihak. Adanya norma tersebut berdasarkan kesepahaman bersama akan kepentingan masing-masing yang dapat diselesaikan secara bersama tanpa merugikan siapapun (Bigoness, 1984).

Terkait dengan konflik di Papua Pemerintah telah melakukan banyak upaya untuk menyelesaikannya. Namun, upaya pemerintah ini belum bisa menghasilkan proses resolusi yang sempurna. Dan salah satu upaya juga dilakukan terkait resolusi konflik adalah melalui jalur negosiasi. Negosiasi menjadi pilihan yang terbaik dengan membuka ruang dialog antara Pemerintah Indonesia dengan Masyarakat Papua. Negosiasi menghindari penggunaan kekerasan dalam pendekatan militer yang menjadi sumber utama konflik di Papua. Selain itu dialog sebagai salah satu bentuk komunikasi yang memberikan ruang 
untuk terjalinnya suatu proses pencarian, pengekspresian pemikiran dan perasaan yang dilakukan antara pihak yang berkonflik. Karena pada hakikatnya apapun konteks hubungan antar manusia baik dalam bentuk kerjasama, persaingan bahkan dalam suasana konflik pasti membutuhkan komunikasi (Sudira, 2017). Oleh karena itu, dalam suatu proses negosiasi sangat penting untuk menganalisis terkait aktor, tuntutan dari setiap aktor dan bagaimana proses negosiasi tersebut, sebagai upaya mencari penyelesaian konflik.

\section{Aktor Negosiasi Konflik Papua}

Sejak tahun 1960, Rakyat Papua menuntut pemisahan dari Indonesia. Tuntutan rakyat Papua ini termotivasi oleh serangkaian permasalahan sejarah, ekonomi dan politik yang terjadi di Papua (Adhiat, 2019).Untuk mengatasi tuntutan dimaksud, maka proses negosiasi dilakukan baik secara internal maupun eksternal dengan melibatkan banyak aktor yang terkait dengan konflik di Papua. Aktor-aktor tersebut diantaranya dari pihak pemerintah baik Pemerintah Pusat, Pemerintah Daerah (Gubernur/Bupati) maupun anggota TNI/Polri yang bertugas menjaga perdamaian di Papua. Selain itu, negosiasi juga harus melibatkan Kelompok Tentara Pembebasan Nasional/Organisasi Papua Merdeka (TPN/OPM), Kepala Suku/Tokoh Agama, maupun masyarakat sipil di Papua. Keterlibatan banyak pihak dalam proses negosiasi ini disebabkan aktor-aktor tersebut memiliki posisi dan peran yang sangat penting terkait konflik di Papua. Posisi dan peran masing-masing aktor dalam konflik Papua dapat dijelaskan sebagai berikut.

1. Pemerintah Pusat dan Daerah

Pada umumnya muncul banyak pendapat bahwa konflik Papua merupakan tanggung jawab dari Pemerintah Daerah dalam hal ini terkait Pemerintah Provinsi maupun Pemerintah Kabupaten/Kota. Hal ini sangat keliru karena apabila dianalisa lebih jauh, konflik yang terjadi di Papua adalah bentuk protes masyarakat Papua terhadap kebijakan Pemerintah Pusat yang dianggap tidak "pro-Papua" sejak Papua berintegrasi dengan Indonesia. Kebijakan tersebut terkait fenomena yang terjadi di Papua sekarang ini, dimana diwarnai oleh kondisi keamanan yang tidak menentu; kepincangan pembangunan yang tidak mencerminkan asas keadilan; ketidakberpihakan pada orang asli Papua, tingkat kerusakan yang parah pada ekosistem hutan dan perairan laut; perkembangan ekonomi pasar yang lebih menguntungkan warga pendatang, konflik sosial yang diduga direkayasa, tingginya mobilitas penduduk dari luar Papua, serta sistem pemerintahan baik pada tingkat provinsi maupun kabupaten/kota yang sarat dengan praktik KKN, bahkan sistem suku, kekeluargaan, atau dinasti diterapkan dimana-mana di tanah Papua, baik di Provinsi Papua maupun Papua Barat (Mambraku, 2015). Oleh karena itu posisi dan peran pemerintah pusat sangat penting dalam proses negosiasi konflik Papua.

Pemerintah Pusat mencari solusi untuk penanganan konflik Papua dengan merumuskan kebijakan yang sesuai. Salah satu upaya pemerintah dalam meredam konflik adalah dengan mengeluarkan Undang-Undang Nomor 45 Tahun 1999 tentang Pembentukan Provinsi Irian Jaya Tengah, Provinsi Irian Jaya Barat, Kabupaten Paniai, Kabupaten Mimika, Kabupaten Puncak Jaya dan Kota Sorong yang memecah Provinsi Irian Jaya menjadi Provinsi Irian Jaya Bagian Timur, Tengah dan Barat. Pemecahan Papua dengan membentuk provinsi-provinsi baru ternyata dianggap gagal total karena mendapatkan penolakan luas dari masyarakat Papua (Wospakrik, 2016). Pemerintah juga mengeluarkan Undang-Undang Nomor 21 Tahun 2001 tentang Otonomi Khusus Papua (Otsus Papua) yang memberikan kewenangan yang lebih luas bagi pemerintah provinsi dan rakyat Papua untuk mengatur dan mengurus diri sendiri di dalam kerangka NKRI (Hukumonline.com, 2001). 
Pelaksanaan Otsus ini ternyata tidak memberikan manfaat yang dapat dirasakan oleh masyarakat Papua. Selain itu, kebijakan tentang pembentukan provinsi baru di Tanah Papua, pembentukan Daerah Otonom Baru (DOB), eksploitasi pertambangan, transmigrasi, dan kebijakan pemerintah lainnya juga masih dianggap gagal untuk memberi dampak yang signifikan bagi kesejahteraan masyarakat Papua (Jawa Pos, 2019).

Di sisi lain, pemerintah daerah adalah perwakilan Pemerintah pusat di daerah. Pemerintah daerah mempunyai peran ganda, dimana dapat sebagai pemacu pembangunan atau pemicu konflik. Sebagai pemacu pembangunan karena pemerintah daerah lebih mengetahui secara teknis masalahmasalah pembangunan dan kebutuhan masyarakat di wilayahnya masingmasing. Pemerintah daerah juga mempunyai pengalaman sukses dan gagal dalam melaksanakan pembangunan. Semua pengalaman ini merupakan kekayaan yang dapat dibagikan dan digunakan dalam mencari penyelesaian komprehensif atas konflik Papua. Sedangkan sebagai pemicu konflik hal ini terkait banyaknya penyalahgunaan kewenangan yang dilakukan oleh pemerintah daerah yang dapat merugikan dan menimbulkan konflik di Papua. Oleh karena itu, keterlibatan pemerintah daerah baik pada tingkat Provinsi maupun Kabupaten/Kota dalam proses negosiasi konflik Papua juga sangat penting. Mereka tidak boleh menganggap dirinya sebagai satusatunya pemangku kepentingan yang menentukan isi dari kebijakan tentang Papua. Mereka perlu mengakui adanya pemangku-pemangku kepentingan yang lain dalam masyarakat Papua.

Terkait peran pemerintah pusat dalam penyelesaian konflik di Papua, terdapat aktor lain yang juga memiliki peran penting dalam penegakan hukum dan menjaga stabilitas keamanan di Papua. Aktor tersebut adalah anggota TNI/Polri yang bertugas di tanah Papua. Anggota TNI/Polri mengumpulkan banyak informasi dari berbagai sumber, termasuk semua pihak yang dipanggil sebagai saksi maupun tersangka. Informasi yang dimiliki sangat berguna dalam pencarian solusi penyelesaian konflik di Papua. Perubahan pendekatan dalam menyelesaikan konflik dimana pendekatan dialog menjadi pilihan utama dibandingkan menggunakan pendekatan militer, membuka kesempatan untuk memanfaatkan anggota TNI/Polri sebagai aktor negosiasi. Anggota TNI/Polri juga merupakan aktor utama yang berhadap langsung dengan kelompok separatis maupun masyarakat sipil dalam situasi konflik (Sugandi, 2008).

2. Kelompok Kriminal Bersenjata/ Organisasi Papua Merdeka (KKB/OPM)

Kelompok ini bergerilya di hutan dan menyebar di sejumlah wilayah di Tanah Papua dan masih aktif hingga sekarang. Pada tahun 1980-an, pemerintah Indonesia menyebut kelompok TPN ini sebagai Gerakan Pengacau Liar (GPL) dan Gerakan Pengacau Keamanan (GPK). Presiden Jokowi lebih sering menyebut mereka sebagai Kelompok Kriminal Bersenjata (KKB). Mereka dianggap sebagai pelaku dalam sejumlah kasus konflik yang terjadi di Papua sehingga menjadi target pengejaran dari aparat militer.

Operasi militer memberantas OPM dengan menggunakan dan menggandalkan kekuatan senjata tidak mampu mengurangi pengaruh kelompok ini dalam konflik di Papua. OPM akan terus melakukan perjuangannya untuk kemerdekaan Papua dan perjuangan OPM mengalami perkembangan tidak hanya terbatas dengan menggunakan cara kekerasan tetapi juga non-kekerasan dengan memanfaatkan dialog internasional dan media informasi. Walaupun tidak menutup kemungkinan penggunaan senjata masih menjadi pilihan untuk untuk perlindungan diri. Melalui para pemimpinnya yang berada di luar negeri, OPM mulai melibatkan diri dalam sidang maupun konferensi internasional untuk menarik perhatian dunia internasional. Transformasi 
perjuangan OPM yang mulai mengandalkan media non-kekerasan ini atau dengan menggunakan cara yang lebih "soff", maka membuka kesempatan bagi pemerintah Indonesia untuk dapat melibatkan mereka dalam proses negosiasi konflik Papua (Zahra Chairani, 2019).

\section{Kepala Suku/Tokoh Agama}

Para pemimpin informal seperti kepala suku dan tokoh agama sangat penting perannya dalam memelihara kebersamaan yang damai di dalam masyarakat Papua. Para kepala suku masih didengarkan dan dihormati dengan baik di antara akar rumput (orang Papua asli). Kesetiaan kesukuan di dalam kerangka primordial memberntuk hubungan-hubungan di antara orang asli Papua dan membangun identitas bersama sebagai anak adat Papua. Kepemimpinan yang kharismatik dari para kepala suku ini memberikan kekuasaan untuk mempengaruhi dan menggerakkan masyarakat mereka. Posisi kepala suku merupakan status bawaan sebagai hasil warisan antar generasi. Oleh karena memiliki pengaruh yang sangat besar dalam komunitas adat, para kepala suku sering dipakai untuk mengalirkan dan menyebarkan informasi tertentu termasuk indoktrinasi dari pihak-pihak yang berkepentingan atau para pengusaha konflik dalam rangka membangun opini publik (Sugandi, 2008). Oleh karena itu, peran Kepala suku sangat penting dilibatkan dalam proses negosiasi penyelesaian konflik dipapua.

4. Masyarakat Sipil

Masyarakat sipil dalam hal ini adalah masyarakat asli Papua yang merasakan dampak secara langsung dari semua jenis konflik yang terjadi di negeri leluhurnya. Mereka sering dicurigai sebagai separatis sehingga diperlakukan sebagai ancaman oleh pemerintah terutama oleh aparat keamanan. Mereka hidup dalam tekanan konflik yang terjadi sekian lama sehingga memberikan trauma dan ingatan penderitaan (memoria passionis). Ingatan penderitaan membuat sebuah bangsa mengambil tindakan tertentu. Memori ini membentuk pandangan mereka tentang dirinya, pemerintah, orang nonPapua, dan berbagai peristiwa sosial dan politik yang terjadi di Papua baik dalam skala kecil maupun skala besar. Mereka biasanya tidak diajak dan dilibatkan dalam proses membuat kebijakan yang akan mempunyai dampak langsung terhadap hidup dan masa depannya. Oleh sebab itu, tidaklah mengherankan apabila mereka menyatakan penolakan terhadap kebijakan atau solusi tertentu, sekalipun kebijakan tersebut dirumuskan dengan jelas dan ditetapkan pemerintah. Penolakan ini dilakukan bukan semata-mata karena tidak setuju dengan isi dari kebijakan tersebut, tetapi karena tidak terlibatnya mereka dalam merumuskan kebijakan tersebut sehingga kebijakan tersebut tidak mendapat legitimasi dari masyarakat Papua (Taum, 2015). Dengan demikian, masyarakat sipil merupakan aktor penting dan menjadi tujuan dalam proses negosiasi.

5. Aktor Eksternal

Selain aktor internal yang telah dijelaskan di atas, penyelesaian konflik Papua juga harus melibatkan aktor ekternal dalam hal ini terkait keberadaan Freeport di Papua. Freeport merupakan perusahaan tambang terbesar milik Amerika Serikat. Keberadaan Freeport di Papua juga mempengaruhi pergolakan konflik di wilayah tersebut. Freeport melakukan eksplorasi dan eksploitasi sumber daya mineral di Papua khususnya di wilayah Timika. Wilayah ini sering menjadi medan konflik dan kekerasan antar suku maupun yang melibatkan kelompok bersenjata dan aparat keamanan. Konflik ini terkait kegiatan operasional pertambangan yang berdampak pada lingkungan tempat tinggal orang asli Papua yang merupakan pemilik hak ulayat. Data yang dikumpulkan dalam Kajian Dinamika Konflik dan Kekerasan di Indonesia, memperlihatkan bahwa konflik tentang sumber daya alam ini menyumbang 38 persen dari total 
konflik dan kekerasan yang ada di wilayah ini. Rata-rata ada sebanyak 86 insiden per tahun yang terjadi lantaran perebutan sumber daya alam (Yanuarti, 2002). Oleh karena itu, proses negosiasi juga harus melibatkan Freeport untuk menyelesaikan konflik terkait sumber daya alam di Papua.
Berdasarkan penjelasan terkait aktor negosiasi konflik Papua, maka dapat disimpulkan bahwa peran dari setiap aktor tersebut dalam proses negosiasi konflik Papua adalah sebagai berikut.

Tabel 1. Peran Aktor-Aktor dalam Proses Negosiasi Konflik Papua

\begin{tabular}{lrr}
\hline \multicolumn{1}{c}{ Aktor } & Jenis Aktor \\
\hline $\begin{array}{l}\text { Pemerintah Pusat dan } \\
\text { Daerah }\end{array}$ & Internal \\
& & \\
& & \\
& \\
Kelompok & Kriminal & Internal \\
Bersenjata & (KKB)/ & \\
Organisasi & Papua & \\
Merdeka (OPM) & &
\end{tabular}

Kepala Suku/Tokoh Agama

Masyarakat Sipil
Internal

Pemerintah Pusat dan Daerah berperan penting dalam proses negosiasi, dimana pemerintah mengeluarkan aturan atau kebijakan dalam penyelesaian konflik Papua. Selain itu, pemerintah juga berperan sebagai fasilitator dalam proses negosiasi. Pemerintah memfasilitasi berlangsungnya negosiasi dan menampung semua aspirasi yang disampaikan selama proses negosiasi, sehingga dapat negosiasi dapat menghasilkan keputusan yang benar-benar menguntungkan semua pihak.

Peran aktor ini juga penting dalam proses negosiasi, dimana kelompok ini sering melakukan gerakan separatis dengan berbagai macam cara. Keterlibatan kelompok ini dalam diperlukan guna mengetahui semua sumber persoalan yang terjadi di Papua. Selain itu, ada proses penimbangan untuk mencari solusi yang sesuai. Negosiasi bisa terjadi tentunya dengan adanya persetujuan dari kelompok ini. Tetapi yang harus diperhatikan adalah persyaratan yang diajukan sebelum proses negosiasi.

Para pemimpin informal seperti kepala suku dan tokoh agama sangat penting perannya dalam memelihara kebersamaan yang damai di dalam masyarakat Papua. Para kepala suku masih didengarkan dan dihormati dengan baik di antara akar rumput (orang Papua asli). Kepemimpinan yang kharismatik dari para kepala suku ini memberikan kekuasaan untuk mempengaruhi dan menggerakkan masyarakat mereka. Sama halnya dengan tokoh agama. Oleh karena pengaruh mereka yang sangat besar dalam komunitas adat dan agama, maka mereka sangat diperlukan dalam proses negosiasi. Peran mereka adalah sebagai fasilitator dalam proses negosiasi konflik. Selain itu mereka juga dapat membantu mengalirkan dan menyebarluaskan informasi tertentu termasuk indoktrinasi dari pihak-pihak yang berkepentingan atau para pengusaha konflik dalam rangka membangun opini publik.

Internal Masyarakat sipil adalah mereka yang merasakan dampak dari konflik yang terjadi. Dampak yang terjadi ini menyebabkan adanya memoria dan trauma berkepanjangan. Tidak hern juga kalau mereka sering tidak menerima kebijakan pusat. Oleh karena itu, masyarakat juga memiliki peran penting dalam proses negosiasi. Dengan terlibat dalam proses negosiasi, dapat diketahui apa yang menjadi keinginan dari masyarakat dalam upaya menyelesaikan konflik Papua. 
Freeport $\quad$ Eksternal Salah satu tuntuan dari negosiasi adalah terkait dengan keberadaan Freeport di tanah Papua yang sering menjadi salah satu penyebab konflik. Oleh karena itu, keterlibatan Freeport dalam proses negosiasi memiliki peran yang penting sebagai salah satu pihak yang memberikan keputusan terhadap penyelesaian konflik.

\section{Tuntutan Negosiasi Konflik Papua}

Konflik yang terjadi di Papua berlangsung sangat lama dan mengalami perubahan dalam perjuangan dan tuntutannya kepada Pemerintah Indonesia. Setelah referendum PERPERA, penanganan konflik di Papua dilakukan dengan menggunakan pendekatan militer yang menyebabkan banyak terjadi pelanggaran Hak Asasi Manusia (HAM) dan pengabaian hak-hak dasar penduduk asli Papua. Hal ini menyebabkan munculnya tuntutan "Kemerdekaan Papua" yang diserukan oleh para pejuang OPM. Mereka tidak akan menyerah dengan alasan apapun sebelum kemerdekaan bangsa Papua terwujud dari penjajahan Indonesia.

Konflik Papua terus berlanjut dengan keberadaan Freeport di tanah Papua. Freeport mendirikan berbagai sarana dan prasarana modern lainnya di tanah ulayat. Alih-alih mensejahterahkan masyarakat, pembuatan dan pendirian berbagai sarana dan prasarana itu pada dasarnya hanya dilakukan demi kepentingan eksploitasi pertambangan yang mengakibatkan hilangnya hak ulayat atas tanah, rusaknya sistem sosial-ekonomi, rusaknya lingkungan hidup dan sumber daya alam akibat perubahan ekosistem, termasuk terjadinya berbagai tindak kekerasan yang dapat dikategorikan sebagai pelanggaran HAM berkepanjangan, ancaman bahan kimia yang membahayakan, serta intimidasi dan stigmatisasi sebagai anggota OPM (Soares, 2019).

Keberadaan Freeport juga meresahkan pemilik hak ulayat yaitu suku Amungme dan Kamoro serta lima suku lainnya. Melalui Forum Pemilik Hak Sulung (FPHS) menyampaikan pesan warga pemilik hak ulayat yaitu meminta agar DPRD maupun DPRP, Pemerintah Kabupaten Mimika serta Pemerintah Provinsi bahkan Pemerintah Pusat dalam mendukung perjuangan mereka dengan membuat Peraturan Daerah Khusus (Perdasus) atau Peraturan Gubernur (Pergub) terkait status kepemilikan hak ulayat dan juga menyertakan mereka dalam pembagian saham Freeport maupun Izin Usaha Pertambangan Khusus (IUPK). Selain itu, masyarakat pemilik hak ulayat juga bersepakat apabila perjuangan mereka tidak dikabulkan hingga batas waktu tahun 2021, maka mereka akan menutup tambang Freeport yang beroperasi dikawasan mereka. Pemilik hak ulayat pun menuntut agar Freeport membayar ganti rugi materil sebesar US $\$ 2,5$ miliar dan kerugian imateril sebesar US\$ 30 miliar (BBC.com, 2017). Masyarakat merasa tidak nyaman dengan kerusakan lingkungan yang disebabkan oleh aktivitas pertambangan Freeport. Maka dalam pembahasan selanjutnya Pemerintah Indonesia mulai menuntut divestasi saham Freeport sebesar 51 persen.

Selain tuntutan perjuangan OPM terkait kemerdekaan Papua dan pemilik hak ulayat yang menentang keberdaaan Freeport, konflik Papua kembali memanas dengan peristiwa diskriminasi rasial dan pengusiran Mahasiswa Papua yang terjadi di Malang dan Surabaya tanggal 16 Agustus 2019. Peristiwa tersebut mengakibatkan gejolak di beberapa kota di Papua yang mengakibatkan pengrusakan dan pembakaran fasilitas umum. Perwakilan dari DPRD Papua dan Papua Barat mengambil langkah untuk menyurati Presiden Jokowi terkait dengan penyelesaian konflik di Bumi Cendrawasih. Selain itu, Forum 
Pimpinan DPRD dan Asosiasi DPRD Kabupaten Seluruh Indonesia (ADKASI) setanah Papua menyampaikan juga mengajukan 8 (delapan) tuntutan kepada Pemerintah (detiknews.com, 2019) terkait peristiwa tersebut yaitu:

1. Dialog antara Pemerintah Pusat dan Tokoh-tokoh Papua, khususnya Tokoh-tokoh yang dipandang memiliki ideologi yang konfrontatif atau bersebrangan seperti ULMWP (The United Liberation Movement for West Papua) dan KNPB( Komite Nasional Papua Barat). Dialog dimaksud agar dilakukan dengan melibatkan pihak ketiga yang independen, netral, dan objektif dalam menyelesaikan akar persoalan politik, HAM dan demokrasi di Tanah Papua. Kehadiran pihak ketiga tersebut krusial dan strategis untuk dapat memperkuat rasa saling percaya (mutual trust) dari berbagai elemen masyarakat;

2. Mendesak kepada pemerintah pusat untuk segera melakukan revisi terhadap Undang-Undang Nomor 21 Tahun 2001 tentang Otsus Papua;

3. Menarik pasukan Non-Organis TNI dan Polri di Papua dan Papua Barat;

4. Mendorong pembentukan pemekaran daerah otonomi baru khusus bagi Provinsi Papua dan Papua Barat;

5. Meminta kepada Presiden Indonesia melalui Menteri Dalam Negeri dan Kapolri memfasilitasi pertemuan dengan beberapa kepala daerah yang wilayahnya menjadi pusat pendidikan pelajar mahasiswa Papua dan Papua Barat untuk mendapatkan jaminan keamanan;

6. Mendorong terbentuknya Komisi Kebenaran, Keadilan dan Rekonsiliasi (KKKR) guna menyelesaikan sejumlah kasus pelanggaran HAM di Tanah Papua;

7. Meminta Menteri Dalam Negeri memfasilitasi pertemuan Gubernur,
Bupati/Walikota, MRP/MRPB (Majelis Rakyat Papua dan Majelis Rakyat Papua Barat), DPR daerah pemilihan Papua dan Papua Barat, pimpinan DPRD Provinsi, pimpinan DPRD Kabupaten/Kota se-provinsi Papua dan Papua Barat dengan presiden untuk menyampaikan permasalahan yang terjadi di tanah Papua;

8. Penegakan hukum yang transparan, terbuka, jujur, dan adil terhadap pelaku rasisme di Surabaya, Malang dan Makassar.

Tuntutan yang disampaikan ini menuntut adanya dialog antara pemerintah dan perwakilan masyarakat Papua untuk dapat merumuskan langkah yang diambil dalam upaya menyelesaikan konflik dan pemulihan perdamian di tanah Papua.

\section{Proses Negosiasi Konflik Papua}

Proses negosiasi terkait konflik di Papua terus berlangsung dan belum memberikan hasil yang sempurna. Namun, negosiasi merupakan proses terbaik dalam mencari solusi yang dapat diterima oleh kedua pihak dalam menyelesaikan konflik yang luas dan berkepanjangan ini. Konflik yang terjadi di Papua melibatkan banyak pihak dengan tuntutan dan penyebab konflik yang berbeda. Oleh karena itu hasil dan kemajuan dalam proses negosiasi juga berbeda. Dalam hal ini, dibahas proses negosiasi konflik terkait tuntutan kemerdekaan Papua, ganti rugi dan divestasi saham Freeport serta penyelesaian isu rasial dan diskriminasi terhadap masyarakat Papua.

1. Negosiasi dengan OPM

Proses negosiasi antara Pemerintah dan OPM memang sulit terwujud. Menurut teori negosiasi, pendekatan yang digunakan adalah negosiasi distributif dimana pada dasarnya hubungan keduanya bersifat "zero-sum-game", keuntungan untuk satu pihak secara otomatis menjadi kerugian bagi pihak lainnya. Bagi Pemerintah, keberadaan OPM yang ingin membuat Papua berpisah dari Negara Kesatuan Republik Indonesia jelas merupakan ancaman bagi 
kedaulatan bangsa dan negara. Serangan-serangan yang dilakukan oleh OPM adalah bentuk usaha untuk menekan dan mengurangi peran Pemerintah yang nantinya akan terlihat tidak mampu melindungi dan menjaga ketertiban wilayah dan masyarakat negaranya. Mengadakan dialog dengan OPM di satu sisi merugikan Pemerintah Indonesia. Kerugian ini terkait dengan legitimasi dimana melakukan negosiasi dengan pemberontak maka Pemerintah mengakui kelompok tersebut sebagai aktor yang sah ataupun setara dengan Pemerintah dan memberikan pembenaran terhadap tujuan yang ingin dicapai oleh mereka (Wilder Alejandro Sanchez dan Erica Illingworth, 2017). Bagi OPM, kehadiran Pemerintah melalui TNI/Polri dan pembangunan infrastruktur juga mendelegitimasi alasannya untuk memerdekakan Papua.

Pemerintah Indonesia berusaha mengatasi kekecewaan dan ketidakpuasan masyarakat Papua dengan mengeluarkan Undang-Undang Nomor 21 Tahun 2001 tentang Otonomi Khusus (Otsus) Papua yang merupakan komitmen Pemerintah dan seluruh rakyat Indonesia untuk mengadopsi perspektif baru dalam menangani permasalahan yang mewarnai kehidupan Provinsi Papua. Sekalipun Otsus sudah berjalan, namun pergolakan di Papua tetap saja terjadi. Keinginan untuk merdeka malah semakin lantang diserukan oleh OPM. Banyak kritik yang dilontarkan kalangan masyarakat terkait pelaksanaan Otsus yang masih sangat lemah, dimana kenyataannya komunitas lokal di Papua tidak banyak mengalami perubahan berarti dan belum mendapat manfaat langsung. Tidak adanya arah kebijakan yang jelas terkait pelaksanaan Otsus dan desentralisasi serta kurangnya transparansi dalam penggunaan dana Otsus. Dana Otsus dipergunakan oleh orang-orang politik dan birokrat Papua untuk meningkatkan kekuasaan mereka sehingga dana Otsus tersebut tidak tersalurkan dengan baik kepada mayoritas penduduk tanah Papua (Firmanto, 2012).
2. Negosiasi terkait PT. Freeport Indonesia

Keberadaan PT. Freeport Indonesia sebagai bentuk investasi asing di tanah Papua juga menimbulkan konflik. Tuntutan ganti rugi terkait tanah ulayat dan dampak lingkungan yang ditimbulkan oleh kegiatan ekplorasi dan eksploitasi pertambangan di tanah Papua, mendorong Pemerintah Indonesia untuk melakukan negosiasi dengan pihak Freeport. Pemerintah menuntut nasionalisasi terhadap saham Freeport sebesar 51 persen (divestasi saham). Proses negosiasi terkait nasionalisasi ini juga berlangsung cukup lama dan banyak menghadapi kendala. Negosiasi yang dilakukan sejak dari pemberlakuan Kontrak Karya II PT. Freeport Indonesia di Papua tahun 1991 hingga akhirnya disepakati tanggal 12 Juli 2019 melalui pertemuan Pemerintah Indonesia, Freeport McMoran Inc dan Rio Tinto yang menghasilkan Heads of Agreement (HoA). HoA menyatakan bahwa Inalum akan membeli saham Freeport sebesar US $\$ 3,85$ miliar dengan rincian US\$3,5 miliar untuk membayar hak partisipasi (Participating Interest) kepada Rio Tinto dan sisanya US\$ 350 juta untuk membeli saham PT. Indocopper Investama di Freeport (Finance.detik.com, 2019). Dari saham 51 persen saham Freeport yang dimiliki Pemerintah, 10 persennya diberikan kepada masyarakat Papua. Walaupun masih terdapat kekurangan dalam penyelesaian konflik terkait keberadaan Freeport ini, namun berdasarkan pendekatan negosiasi integratif proses negosiasi ini bersifat "win-win solution", dimana pemerintah Indonesia berhasil melakukan divestasi saham Freeport sebesar 51 persen dan Freeport tetap bisa melakukan kegiatan pertambangan di tanah Papua dengan jaminan operasional dan keamanan dari pemerintah Indonesia. Di sisi lain, terkait dengan tuntutan ganti rugi materil dan inmateril suku Amungme dan Komoro sebagai pemilik hak ulayat di kawasan PT. Freeport Indonesia masih belum mencapai kesepakatan. 


\section{Negosiasi terkait Perlakuan Rasial dan Diskriminasi \\ Perlakuan rasial dan diskriminasi} terhadap orang Papua bukan merupakan hal yang baru terjadi. Namun isu ini kembali dibahas akibat runtutan kejadian di Malang dan Surabaya terkait pengusiran mahasiswa Papua. Negosiasi adalah langkah kongkrit yang langsung dipilih oleh Presiden Jokowi untuk mencegah meluasnya dampak dari peristiwa tersebut. Berdasarkan teori negosiasi, pendekatan yang digunakan adalah negosiasi integratif yang mementingkan terselesainya solusi dengan memperhatikan kepentingan pemerintah maupun masyarakat Papua. Dialog antara pemerintah dan masyarakat Papua dilaksanakan untuk menindaklanjuti tuntutan yang disampaikan perwakilan dari Papua dan Papua Barat. Dialog Jakarta-Papua yang dilaksanakan di Istana Negara tanggal 9 Oktober 2019. Pertemuan ini dihadiri oleh 61 Tokoh Papua dan Papua Barat dan diajukan lagi 9 (Sembilan) tuntutan yaitu:

1) Meminta Presiden Jokowi untuk melakukan pemekaran Provinsi 5 (lima) wilayah adat yang terdapat di Provinsi Papua dan Papua Barat;

2) Pembentukan Badan Nasional Urusan Tanah Papua;

3) Penempatan Pejabat-Pejabat Eselon I dan II di Kementerian dan LPMK (Lembaga Pemberdayaan Masyarakat Kelurahan);

4) Pembangunan Asrama Nusantara di seluruh Provinsi dan menjamin keamanan Mahasiswa Papua;

5) Mengusulkan Revisi UndangUndang Nomor 21 Tahun 2001 tentang Otonomi Khusus bagi Provinsi Papua dalam Prolegnas 2020;

6) Menerbitkan Instruksi Presiden untuk pengangkatan ASN (Aparatur Sipil Negara) Honorer di Tanah Papua;

7) Meminta percepatan Palapa Ring Timur Papua;
8) Meminta Presiden Jokowi mengesahkan Lembaga Adat Perempuan dan Anak Papua;

9) Meminta Presiden Jokowi membangun Istana Presiden di Kota Jayapura.

Atas tuntutan yang disampaikan dalam pertemuan tersebut, Presiden Jokowi langsung memberikan respons positif terkait pegangkatan 1.000 Mahasiswa Papua yang baru lulus untuk bekerja di BUMN dan perusahaan swasta. Selain itu, Presiden juga menyetujui pemekaran wilayah yang diminta tetapi hanya untuk dua sampai tiga wilayah saja. Dan yang terakhir Presiden menyetujui untuk membangun Istana Kepresidenan di Jayapura, Papua.

Setelah dilantik menjadi Presiden untuk periode kedua, Presiden Jokowi kembali melakukan kunjungan ke Papua.Kunjungan yang berlangsung tanggal 28 Oktober 2019 digunakan Presiden Jokowi untuk bertatap muka dan berdialog langsung dengan masyarakat korban kerusuhan di Wamena.Dalam kesempatan itu, Presiden menyampaikan kesiapan TNI/Polri dalam menjamin keamanan di Wamena.Presiden juga memerintahkan jajaran Pemerintah Pusat dan Daerah untuk memperbaiki bangunan yang rusak dan menyediakan rumah tinggal serta mengadakan pelatihan bagi 500 anak jalanan di Wamena.Presiden Jokowi meminta masyarakat Papua untuk memupuk kebersamaan dalam membangun Papua yang lebih maju baik infrastruktur maupun sumber daya manusia.Dengan demikian dengan kunjungan tersebut diharapkan dapat membawa kemajuan dalam penanganan konflik di Papua. Dengan berdialog langsung dengan masyarakat Papua khususnya di Wamena memberikan solusi dalam pembangunan perdamaian di Papua serta arah kebijakan yang benar-benar pro-Papua. Pembangunan tidak hanya bertumpu pada pembangunan infrastruktur tetapi harus sejalan dengan pembangunan manusia. 


\section{Dialog Jakarta-Papua}

Dialog Jakarta-Papua adalah istilah yang sering dipakai untuk mengambarkan proses negosiasi yang berlangsung dalam penyelesaian konflik di Papua. Dialog adalah jalan terbaik dalam penyelesaian konflik di Papua karena melihat budaya Melanesia yang mengutamakan musyawarah dalam mencari solusi konflik. Dialog harus terjadi diantara pihak yang berkepentingan. Dialog juga menjadi rekomendasi dari berbagai penelitian dan kajian tentang konflik Papua. Tetapi yang berbeda adalah dialog yang dibangun harus merujuk pada nilai-dilai budaya orang Papua. Dialog Jakarta-Papua harus mencerminkan lima hal terkait budaya Papua(Widjojo, Elisabeth, Pamungkas, \& Dewi, 2008) yaitu:

1. Dialog harus mampu mempertahankan identitasidentitas kultural dan posisi-posisi politik yang berlawanan sebagai sesuatu yang wajar. Unsur-unsur representasi, format, mekanisme, dan agenda dialog harus merupakan kesepakatan pihakpihak yang berkonflik. Semakin tinggi kadar kesepakatan di dalam proses pra-dialog dan dialog, semakin tinggi pula tingkat legitimasi hasil dialog. Semakin tinggi legitimasi hasil dialog, semakin tinggi pula kemungkinan keberhasilan implementasinya;

2. Dialog harus mampu membuka ruang gerak kultural Orang Papua yang lebih besar sehingga suarasuara yang selama ini termarjinalkan akan memiliki ruang yang baik untuk mendefinisikan identitas kultural mereka yang beraneka warna;

3. Pemerintah harus menyadari wujud keragaman persepsi kultural Masyarakat Papua mengenai cara dan mekanisme dialog politik. Keragaman persepsi itu muncul sebagai dampak dari keberagaman budaya dalam pola kepemimpinan tradisional di Papua. Negara harus memaknai ulang pemahaman kultural atas keragaman wajah
Papua yang bervariasi tersebut, sehingga simplifikasi pendekatan elitis yang akan membuat dialog menjadi penuh syarat dan sempit tidak terjadi;

4. Perlu diwujudkan sebuah dialog yang mengarah kepada tercapainya proses rekonsiliasi dan proses permintaan maaf atas kesalahan di masa lalu oleh pemerintah maupun masyarakat Papua; dan

5. Dialog harus mampu merekonstruksi paradigma negara yang melihat Papua selalu sebagai bangsa separatis yang mengusik keutuhan negara. Pemunculan wacana gerakan separatisme oleh pemerintah pusat dinilai sebagai culture of fearyang mengancam jiwa nasionalisme Indonesia. Atas dasar itu, maka kerap kali kekerasan terhadap masyarakat Papua mendapatkan legitimasi negara. Pemahaman salah yang melanggengkan pelanggaran HAM tersebut tentu harus dikikis bahkan dihapuskan sama sekali.

6. Dialog Jakarta-Papua yang mencerminkan budaya Papua ini dapat menjadi rekomendasi bagi Pemerintah dalam menyusun strategi manajemen konflik Papua. Strategi manajemen konflik diterapkan untuk menjadikan konflik dan pemecahan sebagai pendinamisasi dan pengoptimalan pencapaian tujuan organisasi(Sopiah, 2008).

\section{SIMPULAN DAN SARAN}

Konflik yang terjadi di Papua merupakan konflik vertikal yaitu konflik yang terjadi antara Pemerintah Indonesia dan masyarakat Papua. Namun dalam proses penyelesaiannya, negosiasi konflik Papua melibatkan banyak aktor baik aktor internal maupun eksternal terkait peran masingmasing dalam pembangunan perdamaian di Papua. Untuk proses negosiasi internal melibatkan aktor yang berasal dari pihak Pemerintah (pusat dan daerah), OPM, Kepala Suku 
dan Tokoh Agama, serta anggota TNI/Polri yang mendapat penugasan khusus untuk menjaga keamanan di Papua. Sedangkan untuk proses negosiasi yang sifatnya eksternal melibatkan Amerika Serikat terkait keberadaan PT. Freeport Indonesia di Papua. Pemerintah diharapkan dapat memberikan respon yang cepat terhadap tuntutan-tuntutan dari konflik Papua dengan melakukan Dialog Jakarta-Papua untuk merumuskan kesepakatan yang menguntungkan bagi semua pihak. Dialog JakartaPapua harus merujuk pada nilai-nilai budaya orang Papua dan tanpa menggunakan pendekatan militer ataupun kekerasan. Pada akhirnya apabila Pemerintah Indonesia mampu mempertahankan Papua dalam bingkai NKRI, maka Pemerintah Indonesia juga menyatahkan legitimasinya di tanah Papua.

\section{DAFTAR PUSTAKA}

Adhiat, A. (2019). Kenapa Orang Papua Ingin Merdeka? - kbr.id. Retrieved December 25, 2019, from https://kbr.id/nasional/08-

2019/kenapa_orang_papua_ingin_me rdeka_/100254.html

BBC.com. (2017). Tuntutan masyarakat adat Papua dalam negosiasi Freeport - BBC News Indonesia. Retrieved December 26, 2019, from https://www.bbc.com/indonesia/indon esia-39716839

Bigoness, W. J. (1984). Distributive Versus Integrative Approaches to Negotiation: Experiential Learning Through $A$ Negotiation Simulation. Dalam: Developments in Business Simulation \& Experiential Exercises.

Bunga, B. (2003). Analisis Data Penelitian Kualitatif. Jakarta: PT Raja Grafindo Persada.

Centre for Humanitarian Dialogue. (2011). Pengelolaan konflik di Indonesia Sebuah analisis konflik di Maluku, Papua dan Poso. Retrieved from http://www.hdcentre.org/uploads/tx_n ews/64Bahasalndonesiaversion.pdf

Detiknews.com. (2019). Masihkah Ada Harapan Bagi Pengungsi yang Menunggu di Indonesia? Retrieved December 22, 2019, from https://news.detik.com/berita/d4412759/masihkah-ada-harapan-bagi- pengungsi-yang-menunggu-diindonesia

Finance.detik.com. (2019). 51\% Saham Freeport Resmi Milik Indonesia. Retrieved December 26, 2019, from https://finance.detik.com/foto-bisnis/d4232081/51-saham-freeport-resmimilikindonesia?_ga=2.126880845.178609 1111.1577292228 1055046546.1576343928

Firdausi, F. A. (2019). Sejarah Kemerdekaan Papua Barat dari Belanda \& Gabung NKRI. Retrieved December 25, 2019, from https://tirto.id/sejarah-kemerdekaanpapua-barat-dari-belanda-gabungnkri-egyR

Firmanto, T. (2012). Otonomi Khusus Papua; Dinamika dan Solusi Pemecahannya - Kompasiana.com. Retrieved December 26, 2019, from https://www.kompasiana.com/taufik.fir manto/551017d48133117436bc61ae/ otonomi-khusus-papua-dinamika-dansolusi-pemecahannya

Fresno, P. L., Savolainen, T., \& Miranda, S. (2018). Peran Kepercayaan Dalam Negosiasi Integratif. Jurnal Elektronik Managemen Pengetahuan, 16(1), 1322.

Hadari, N. (1992). Instrumen Penelitian Bidang Sosial. Yogyakarta: Gajah Mada University Press.

Hadi, R. P. (2016). Tantangan Keamanan Nasional Indonesia dalam Menyikapi Transformasi Separatisme dan Cyberprotest di Papua. Joint Seminar on Public and International Affairs UUM-Unair, (September 2016), 1-10.

Hames, D. S. (2012). Negotiation: Closing Deals, Settling Disputes, and Making Team Decisions. California: Sage Publications.

Hertz, J. H. (1950). Idealist Internationalism and the Security Dillema. World Politics.

Hukumonline.com. (2001). UU No.21 Tahun 2001 tentang Otonomi Khusus Bagi Provinsi Papua. Retrieved December 25, 2019, from https://www.hukumonline.com/berita/b aca/hol4321/uu-no21-tahun-2001tentang-otonomi-khusus-bagiprovinsi-papua/

Humairoh, S. (2018). Analisis Penggunaan Diplomasi Multi-Jalur Indonesia untuk Mendukung Penyelesaian Konflik Papua Barat Tahun 2009-2018. Universitas Brawijaya. 
Jawa Pos. (2019). Belum Berdampak Signifikan, Dana Otsus Papua Dievaluasi. Retrieved December 25, 2019, from https://www.jawapos.com/nasional/13/ 10/2019/belum-berdampak-signifikandana-otsus-papua-dievaluasi/

Llamazares, O., \& Nieto, A. (2011). Aspectos clave de la negociación internacional. Madrid: ICEX.

Mambraku, N. S. T. (2015). 75 Penyelesaian Konflik Di Tanah Papua Dalam Perspektif Politik. (21), 75-86.

Moleong, L. J. (2002). Metodologi Penelitian Kualitatif. Bandung: Remaja Rosda Karya.

Muttaqin, A. (2014). Otonomi Khusus Papua Sebuah Upaya Merespon Konflik dan Aspirasi Kemerdekaan Papua. Ejournal Universitas Diponegoro, 4.

Nugroho, A. H. (2019). Kebijakan Pemerintah Joko Widodo dan Jusuf Kalla dalam Upaya Membangun Dialog Untuk Penyelesaian Konflik Vertikal Papua Tahun 2014-2019. Journal of Politic and Government Studies, 8.

RA, F. R., Dermawan, W., \& Akim. (2019). Pendekatan Negosiasi Konflik dalam Resolusi Konflik di Sudan Selatan. Jurnal ICMES, 3(July), 53-74.

Rohim, N. (2014). Optimalisasi Otonomi Khusus Papua dalam Peningkatan Kesadaran Hukum Masyarakat guna Meredam Konflik dan Kekerasan. Junal IImu Hukum Universitas Islam Negeri Jakarta, 8.

Rycho, K. (2013). Proses Integrasi Irian Barat Ke Dalam Negara Kesatuan Republik Indonesia. Fakultas IImu Sosial Dan IImu Politik Universitas Sam Ratulangi.

Soares, A. D. J. (2019). The Impact of Corporate Strategy on Community Dynamics: A Case Study of the Freeport Mining Company in West Papua , Indonesia. 11(1), 115-142. Retrieved from https://www.jstor.org/stable/24675258

Sopiah. (2008). Perilaku Organisasi. Yogyakarta: Andi Offset.

Sudira, I. N. (2017). Dialog dalam Resolusi Konflik-Interaktif. Jurnal IImiah Hubungan Internasional, 12(1), 33. https://doi.org/10.26593/jihi.v12i1.254 4.33-42

Sugandi, Y. (2008). Analisis Konflik dan Rekomendasi Kebijakan Mengenai Papua. Friedrich Ebert Stiftung (FES).
Syamsul H. \& Widjajanto, A. (2007). Disintegrasi Pasca Orde Baru: Negara, Konflik Lokal dan Dinamika Internasional. Jakarta: Yayasan Obor.

Taum, Y. Y. (2015). Kekerasan Dan Konflik Di Papua: Akar Masalah Dan Strategi Mengatasinya. Jurnal Penelitian, 19(1), 1-13.

United Nations. (1945). Piagam PBB.pdf.

Waltz, K. N. (1959). Man, The State and War. New York: Colombia University Press.

Widjojo, M. S., Elisabeth, A., Pamungkas, A. C., \& Dewi, R. (2008). Papua Road Map: Negotiating the Past, Improving the Present and Securing the Future. Jakarta: Lembaga IImu Pengetahuan Indonesia.

Wilder A. S. \& Illingworth, E. (2017). Can Governments Negotiate With Insurgents? The Latin American Experience. Small Wars and Insurgencies, 28(6).

Wospakrik, D. (2016). Gerakan Separatisme di Papua mengurai konflik dan solusi penyelesaian Papua Jakarta.

Https://Deckywospakrik. Wordpress.C om/2016/09/07/Gerakan-

Separatisme-Di-Papua-MenguraiKonflik-Dan-Solusi-PenyelesaianPapua-Jakarta/.

Yanuarti, S. (2002). Kemiskinan dan Konflik Papua di Tengah Sumber Daya yang Melimpah. Jurnal Politik Lipi, 33-46.

Zahra Chairani, A. (2019). Konflik Papua: Transformasi Konflik?

Kompasiana.com. Retrieved December 25, 2019, from https://www.kompasiana.com/adellyaz ahrac/5c727b90c112fe202b53ba29/k onflik-papua-transformasi-konflik 